\title{
Effect of stocking density on the growth and survival of Anomalocardia brasiliana (Gmelin, 1791) (Bivalvia: Veneridae) post-larvae
}

\author{
Isabela Bacalhau de Oliveira ${ }^{1}$ Henrique David Lavander ${ }^{2}$ Priscilla Celes Maciel de Lima ${ }^{2}$ \\ Carlos Yure Barbosa de Oliveira ${ }^{* *}$ Danielli Matias de Macedo Dantas ${ }^{4}$ Alfredo Olivera Gálvez ${ }^{2}$
}

\author{
${ }^{1}$ Instituto Federal de Educação, Ciências e Tecnologia de Sergipe (IFS), Estância, SE, Brasil. \\ ${ }^{2}$ Departamento de Pesca e Aquicultura, Universidade Federal Rural de Pernambuco (UFRPE), Recife, PE, Brasil. \\ ${ }^{3}$ Departamento de Aquicultura, Laboratório de Cultivo de Algas, Universidade Federal de Santa Catarina (UFSC), 88061-600, Florianópolis, \\ SC, Brasil. E-mail: yureboliveira@gmail.com. "Corresponding author. \\ ${ }^{4}$ Universidade Federal Rural de Pernambuco (UFRPE), Unidade Acadêmica de Serra Talhada, Serra Talhada, PE, Brasil
}

ABSTRACT: Anomalocardia brasiliana post-larvae were cultured for 28 days to evaluate the effect of stocking density on their growth and survival rate. Three stocking densities were tested 40,80 and 160 post-larvae $\mathrm{cm}^{-2}$, in experimental units (2-L) with static cultivation system and total water renewal at each 48 hours. The experimental design was completely randomized with three treatments and three repetitions each. Stocking density of 40 post-larvae $\mathrm{cm}^{-2}$ reached $1 \mathrm{~mm}$ length within 24 days, while only $18 \%$ of the post-larvae at density of 80 postlarvae $\mathrm{cm}^{-2}$ reached $1 \mathrm{~mm}$ length in the same time. The density of 40 post-larvae $\mathrm{cm}^{-2}$ had the highest specific growth rate, $4.98 \pm 0.08 \%$ day ${ }^{-1}$. The survival rates of post-larvae at lower densities were significantly higher $(53.24 \pm 4.60 \%$ and $52.95 \pm 3.32 \%$, on 40 and 80 post-larvae cm-2, respectively) compared to higher stocking density (31.54 $0.70 \%)$. In the cultivation of A. brasiliana post-larvae, stocking density must be managed during growth. The density of 160 post-larvae $\mathrm{cm}^{-2}$ can only be used until the post-larvae reach $600 \mu m$ in length, then they should be at 40 post-larvae $\mathrm{cm}^{-2}$ density to keep the maximum daily growth rate.

Key words: aquaculture, clams, larviculture, microalgae, West Indian pointed venus.

Efeito da densidade de estocagem sobre o crescimento e sobrevivência de pós-larvas de Anomalocardia brasiliana (Gmelin, 1791) (Bivalvia: Veneridae)

RESUMO: Pós-larvas de Anomalocardia brasiliana foram cultivadas por 28 dias para avaliar o efeito da densidade de estocagem no crescimento e taxa de sobrevivência. Três densidades de estocagem foram testadas: 40, 80 e 160 pós-larvas $\mathrm{cm}^{-2}$, em unidades experimentais (2 L) com sistema de cultivo estatístico e renovação total de água a cada $48 \mathrm{~h}$. O delineamento experimental foi inteiramente casualizado com três tratamentos em triplicata. A densidade de estocagem com 40 pós-larvas $\mathrm{cm}^{-2}$ alcançou 1 mm de comprimento após 24 dias, enquanto apenas $18 \%$ das pós-larvas estocadas a 80 pós-larvas $\mathrm{cm}^{-2}$ atingiram $1 \mathrm{~mm}$ de comprimento no mesmo periodo. A densidade de 40 pós-larvas

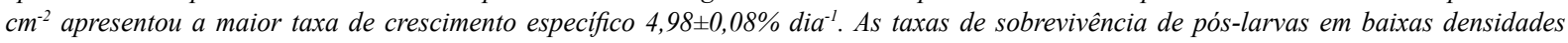
foram significativamente maiores (53,24 $\pm 4,60 \%$ e 52,95 $\pm 3,32 \%$, em 40 e 80 pós-larvas cm $^{-2}$, respectivamente) em comparação com a maior densidade de estocagem (31,54 \pm 0,70\%). Os resultados sugerem que na criação de pós-larvas de A. brasiliana, a densidade populacional deve ser ajustada durante o crescimento. A densidade de 160 pós-larvas $\mathrm{cm}^{-2}$ só pode ser usada até que as pós-larvas atinjam o comprimento de $600 \mu \mathrm{m}$; em seguida deve ser alterada para a densidade de 40 pós-larvas $\mathrm{cm}^{-2}$ para manter a taxa máxima de crescimento diário.

Palavras-chave: aquicultura, amêijoas, larvicultura, microalgas, molusco-de-areia.

\section{INTRODUCTION}

Mollusk production is an important activity within world aquaculture. Although, not a recent activity, mollusk production still has obstacles such as the lack of proper methodologies for domesticating native species and economic viability of production (FAO, 2018). In Brazil, the main mollusk specie produced is Crassostrea gigas, a temperate oyster that, when grows at high temperatures, growth and survival rates may be compromised (POLI, 2004). To make oyster production feasible in the tropical regions of the Brazil, native species such as Crassostrea gasar (CHRISTO \& ABSHER, 2006;
LEGAT et al., 2017) and Crassostrea rhizophorae (GALVÃO et al., 2009; LOPES et al., 2013) are being studied. Moreover, the Brazil stands out in the scenario of mollusk production for being the world's most important producer of the brown mussel Perna perna ( 20,000 tones year ${ }^{-1}$; FAO, 2018).

In addition to the production of oysters and mussels, from the 1990s clams aquaculture developed rapidly throughout the world and contributed to the growth of mollusk production (FANG \& LIN, 2016). However, variations in environmental parameters and larvae availability have already caused oscillations in clams world production (e.g. Ruditapes spp. and Tapes philippinarum; HUO et al., 2018). In Brazil, 
oscillations in clams availability were related to atypical environmental conditions and overfishing, since no management plan has yet been decided. This irregularity has been causing social and economic impacts (SILVA-CAVALCANTI \& COSTA, 2009; CORTE et al. 2017).

Anomalocardia brasiliana (Gmelin, $1791)$ is the most relevant clam for Brazilian fisheries, mainly in Northeastern Brazil (SILVACAVALCANTI \& COSTA, 2009; OLIVEIRA et al., 2011; LAVANDER et al., 2011; OLIVEIRA et al., 2014). It belongs to the Veneridae family and found in place of lives at water depths ranging from 0.5 to 1.5 $\mathrm{m}$ into shallow sandy grounds near mangroves. It is sensitive to environmental variations; high mortality levels are noted during the rainy season which causes large fluctuations in the size and distribution of populations (MONTI et al., 1991; MOUËZA et al., 1999; FUNO et al., 2019).

Ideal stocking density for $A$. brasiliana has been extensively studied. However, most studies have evaluated the growth period in the D-larvae phase to metamorphosis pediveliger (LIU et al., 2010; OLIVEIRA et al., 2014; LIMA et al., 2018), as they are critical stages; larvae are fragile and susceptible to diseases during handling. After the metamorphosis pediveliger, postlarvae become more resistant to handling and can be grown at higher densities, for a longer period (days) until they reach seed size $(1 \mathrm{~mm})$, when they can be transferred to the field (NICOLAS \& ROBERT, 2001; EPELBAUM et al., 2011; LIU et al., 2010).

The evaluation of the stocking density during the post-larval stage aims to find the ideal environmental conditions for the post-larvae to reach seed size in the shortest possible time. In this sense, the present study aimed to evaluate the effect of stocking density on the growth and survival rate of Anomalocardia brasiliana post-larvae in a closed cultivation system.

\section{MATERIALS AND METHODS}

\section{Breeding collection and acclimatization}

A total of 500 Anomalocardia brasiliana brooders (24.50 $\pm 2.00 \mathrm{~mm}$ length) were collected at the beach of Mangue Seco, state of Pernambuco, Brazil (07050'1.19'S, 03450'39.1'W). Brooders were transported to Sustainable Mariculture Laboratory (LAMARSU), linked to the Federal Rural University of Pernambuco. There, the animals already in the final stage of maturation were acclimatized in 500-L tank, during $24 \mathrm{~h}$ and a density of 1 ind $\mathrm{L}^{-1}$, where water quality was under control: temperature $\left(25^{\circ} \mathrm{C}\right), 30$-salinity and dissolved oxygen medium $\left(6 \mathrm{mg} \mathrm{L}^{-1}\right)$, and fed with
Chaetoceros calcitrans $\left(300,000\right.$ cells $\left.\mathrm{mL}^{-1}\right)$.

\section{Release of gametes and larviculture of A. brasiliana}

After acclimatization, the brooders were induced to release gametes, by raising the temperature to $28^{\circ} \mathrm{C}$ and after that, adding $C$. calcitrans $(300,000$ cells $\mathrm{mL}^{-1}$ ), in a 400 -L tanks in stocking density of 4 larvae $\mathrm{L}^{-1}$. After the release of gametes, the eggs were collected in $50 \mu \mathrm{m}$-meshes, counted and placed in $30-\mathrm{L}$ incubators with filtered seawater at $1.5 \mu \mathrm{m}$ and sterilized with sodium hypochlorite at 30 -salinity and total renewal of water every 48 hours.

Eggs were kept in the conical incubators for 15 days until reaching the post-larval stage; in this step, a density of 10 larvae $\mathrm{mL}^{-1}$ was adopted. The larvae were fed with a mixture of microalgae, $C$. calcitrans and Pavlova lutheri, with cells ratio of 1:1 using different algal concentration. From the first to the seventh day 30,000 cells $\mathrm{mL}^{-1}$; from the eighth to the twelfth day 40,000 cells $\mathrm{mL}^{-1}$ and; from thirteenth day until the start of the experiment 50,000 cells $\mathrm{mL}^{-1}$ was used (OLIVEIRA et al., 2014). The feeding was adjusted by observing the algal consumption, by daily counts of residual algal using a Neubauer chamber. In addition, water quality also was under control: temperature $\left(25 \pm 1{ }^{\circ} \mathrm{C}\right), 30$-salinity and dissolved oxygen (over $5 \mathrm{mg} \mathrm{L}^{-1}$ ).

Experimental design and management of post-larvae At the beginning of the experiment postlarvae with 15-day-old were measured $(n=30)$ and had an average size of $307.89 \pm 50.92 \mu \mathrm{m}$ in length (measured between the anterior and posterior ends of the shell). Post-larvae were transferred to experimental units (2-L plastic containers), which had a center $10 \mathrm{~cm}$ PVC cylinder (area $78.5 \mathrm{~cm}^{2}$ ) was placed in suspension, with a mesh of $250 \mu \mathrm{m}$ in the bottom, and an airlift for water circulation (Figure 1). The post-larvae were cultured for 28 days, in three different stocking densities: 40, 80 and 160 postlarvae $\mathrm{cm}^{-2}$, with three replicates each, in a closed water circulation system with full exchange at each 48 hours. This system proved to be efficient for the three densities tested and it was possible to maintain water quality at optimum levels for this species: temperature $\left(25^{\circ} \mathrm{C}\right), 30$-salinity and dissolved oxygen (over $5 \mathrm{mg} \mathrm{L}^{-1}$ ). During the experiment, the feeding was composed by $C$. calcitrans and $P$. lutheri and offered daily, in the same cell ratio (1:1), using algal concentration of 50,000 cells $\mathrm{mL}^{-1}$, over 28 days.

\section{Post-larval development}

For the evaluation of post-larval growth, $1 \mathrm{~mL}$ samples were taken from experimental units every 7 days. Images were taken by a camera attached 


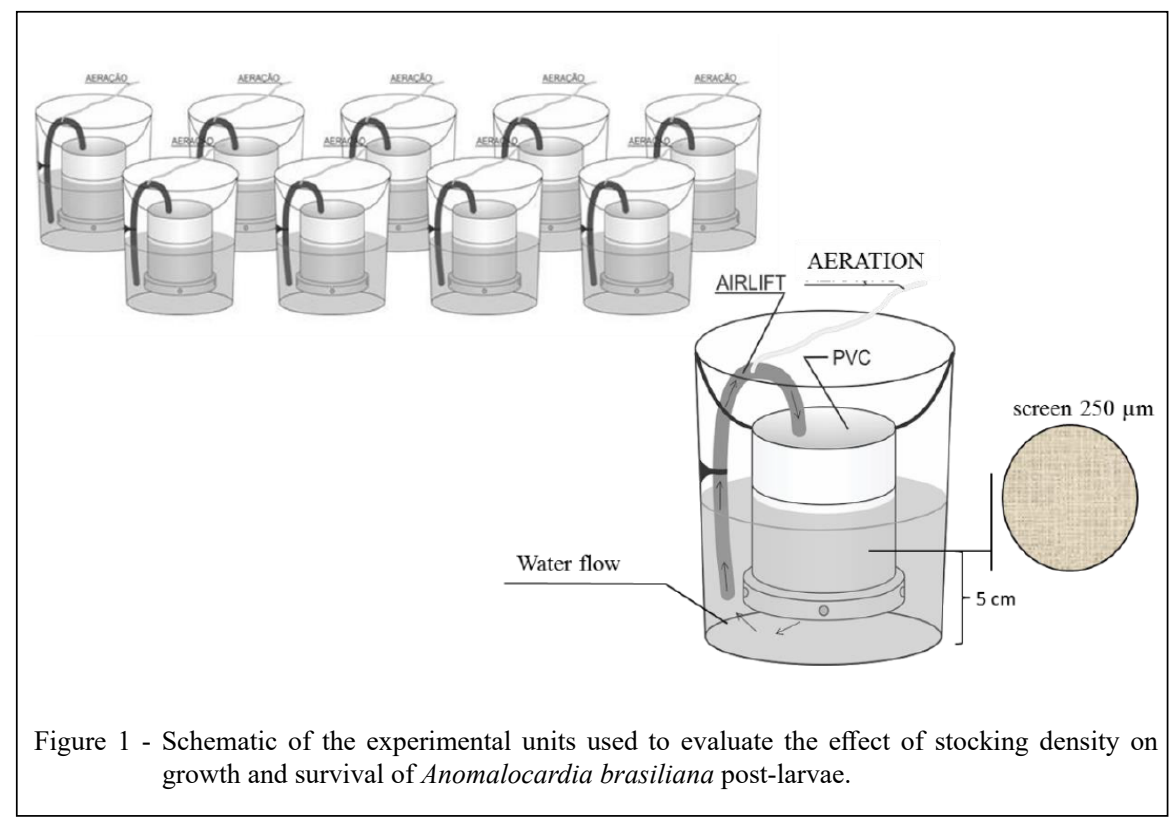

to a light microscope (Coleman - N107 LED), using a Sedgewick-Rafter chamber. Each week, random photos of 30 post-larvae of the experimental units were taken. For evaluating the growth of post-larvae, length measurements (maximum antero-posterior dimension) (OLIVEIRA \& OLIVEIRA, 1974) were taken with the software ImageTool version 2.0 (Texas University, Health Science Centre, San Antonio, USA).

The growth rate of post-larvae was estimated using the following formula (LIU et al. 2006):

$\mathrm{SGR}=100(\ln L 2-\ln L 1) / \mathrm{T}$, where $\mathrm{SGR}$ stands for specific growth rate $\left(\% \mathrm{day}^{-1}\right) ; \mathrm{L} 1, \mathrm{~L} 2$, stand for shell length at the beginning and at the end of each experiment day, respectively, and " $T$ " duration of experiment (days).

At the end of experiment, the surface coverage rate (SCR) was estimated from the covered area $(\mathrm{AO})$ : $\mathrm{AO}=[(\mathrm{L} / 2) \times(\mathrm{H} / 2) \times \pi] \times \mathrm{N}$ where $\mathrm{AO}$ is the area occupied by shells, $\mathrm{L}$ is the average length of the shells, $\mathrm{H}$ is the mean height and $\mathrm{N}$ is the total number of post-larvae per experimental unit. The result was correlated to the background area (78.5 $\left.\mathrm{cm}^{2}\right)$ to find the SCR (\%), methodology by LIU et al. (2010).

For the evaluation of post-larval survival at the end of the cultivation, the entire volume of each experimental unit was filtered, concentrating the postlarvae in $50 \mathrm{~mL}$ containers, from which three samples of $1 \mathrm{~mL}$ were taken; the individuals were counted using a Sedgewick-Rafter chamber.

\section{Statistical analysis}

The survival data, length and growth, was previously checked for normality using the KolmogorovSmirnov test and the Cochran C homogeneity of variance test. Analysis of Variance (ANOVA one-way) was used to determine the effect of density on the growth and on the survival of post-larvae among the sampling intervals (7 days). Tukey's test was performed to detect how the treatment interfered in the average results obtained, between treatments differ significantly, at a significance level of $5 \%(p<0.05)$. Data are presented as mean \pm standard error.

\section{RESULTS}

Average lengths of $A$. brasiliana postlarvae stocked at different densities at 7-day intervals are shown in figure 2. Differences $(P>0.05)$ in lengths of post-larvae at 40 post-larvae $\mathrm{cm}^{-2}$ were identified on the $14^{\text {th }}$ day of cultivation (length $814.54 \pm 56.71 \mu \mathrm{m}$ ). The post-larvae at the highest stocking density $(160$ post-larvae $\left.\mathrm{cm}^{-2}\right)$ had lower average lengths $(P<0.05)$ at the end of the $28^{\text {th }}$ day of cultivation, with 791.21 $\mu \mathrm{m}$ of average lengths; while the other lengths, different from each other $(P<0.05)$, were $1,249.77$ $\mu \mathrm{m}\left(40\right.$ post-larvae $\left.\mathrm{cm}^{-2}\right)$ and $972.71 \mu \mathrm{m}$ (80 postlarvae $\left.\mathrm{cm}^{-2}\right)$. On the $24^{\text {th }}$ day, all post-larvae cultivated at 40 post-larvae $\mathrm{cm}^{-2}$ density reached $1,000 \mu \mathrm{m}$ in length; $18 \%$ of the post-larvae grown at 80 postlarvae $\mathrm{cm}^{-2}$ reached the same length after 28 days of 


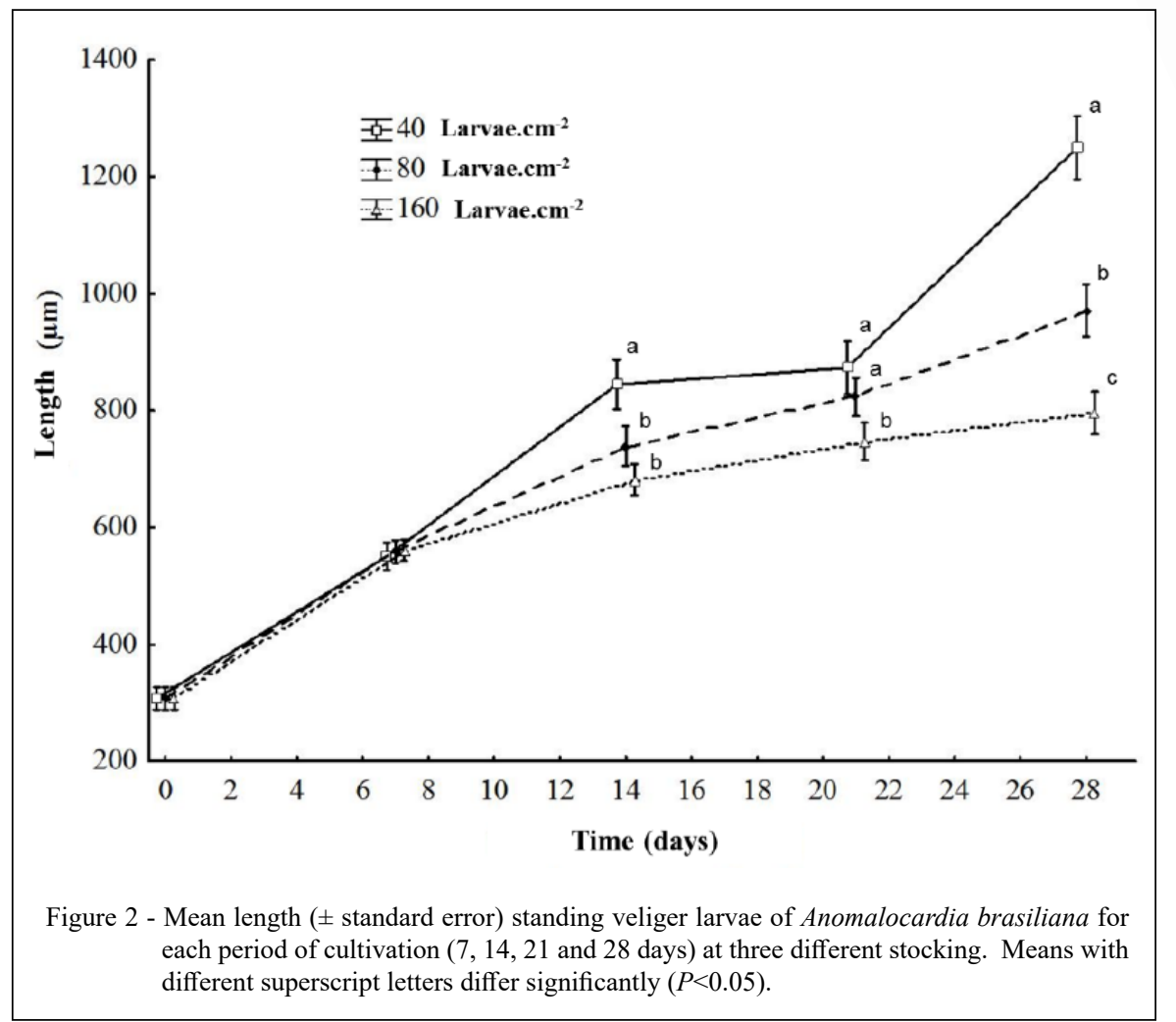

cultivation, and post-larvae grown at 160 post-larvae $\mathrm{cm}^{-2}$ did not reach this length at all (Table 1). The same was observed when assessing the height, the treatment differed significantly $(P<0.05)$ from each other and the one with the highest density (160 post-larvae $\mathrm{cm}^{-2}$ ) presented the lowest height.

Average larval survival final at lower densities (40 and 80 post-larvae $\left.\mathrm{cm}^{-2}\right)$ was $53.24 \pm 4.60 \%$ and $52.95 \pm 3.32 \%$, respectively, differing significantly from the rate at the highest stocking density $(31.54 \pm 0.70 \%)$.

The highest SCR was reported in 80 postlarvae $\mathrm{cm}^{-2}(28.83 \%)$. Because of the high mortality of the treatment with 160 post-larvae $\mathrm{cm}^{-2}$, the SCR value of this treatment did not differ $(P>0.05)$ from the treatment with lower density, being $25.06 \%$ and $23.27 \%$, for 40 and 160 post-larvae $\mathrm{cm}^{-2}$, respectively.

Table 2 shows the post-larvae SGR at the three different stocking densities. The fastest growth occurred in the first seven days of the experiment. The lowest density (40 post-larvae $\mathrm{cm}^{-2}$ ) showed the highest growth rate until the fourteenth day, differing from the two other densities evaluated $(P<0.05)$. After 21 days of cultivation, growth rate dropped sharply at all three densities (Table 2).

\section{DISCUSSION}

Food is a growth limiting factor of bivalve mollusc cultured in high densities (LOOSANOFF \& DAVIS 1963; SPRUNG, 1984). To study the effect of stocking density on a target species, one should ensure that food does not exceed a maximum and minimum desirable concentration (LIU et al., 2010). In this study, the residual algal was checked daily, and adjusted as necessary, to maintain the same concentration in each dietary treatment and ensure that food was not lacking, especially at the highest density. Thus, it is assumed that food was not a limiting factor.

In the present study, it was observed that the stocking density impairs the development of post-larvae and the greatest growth was obtained at a density of 40 post-larvae $\mathrm{cm}^{-2}$, with $1,249.77 \mu \mathrm{m}$ and $1,156.31 \mu \mathrm{m}$ in length and height, respectively. Once, high stocking densities in the cultivation of bivalve post-larvae can cause reduced growth. This can be attributed not only to food shortage, but also to low confinement space, which will cause deterioration in the water quality (RAGHAVAN \& GOPINATHAN, 2008; VELASCO \& BARROS, 
Table 1 - Post-larval growth of Anomalocardia brasiliana in three different storage densities cultivated for 28 days.

\begin{tabular}{|c|c|c|c|}
\hline \multirow[t]{2}{*}{ Parameter } & 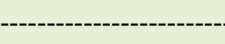 & --Treatments--------- & -------------------- \\
\hline & 40 post-larvae $\mathrm{cm}^{-2}$ & 80 post-larvae $\mathrm{cm}^{-2}$ & 160 post-larvae $\mathrm{cm}^{-2}$ \\
\hline Length $(\mu \mathrm{m})$ & $1,249.77 \pm 27.08^{\mathrm{a}}$ & $972.71 \pm 22.49^{b}$ & $791.21 \pm 17.36^{\mathrm{c}}$ \\
\hline Height $(\mu \mathrm{m})$ & $1,156.31 \pm 25.33^{\mathrm{a}}$ & $888.52 \pm 21.02^{b}$ & $735.46 \pm 15.56^{\mathrm{c}}$ \\
\hline Survival (\%) & $53.24 \pm 4.60^{\mathrm{a}}$ & $52.94 \pm 3.32^{\mathrm{a}}$ & $31.54 \pm 0.70^{b}$ \\
\hline SCR $(\%)$ & $22.26 \pm 1.97^{b}$ & $28.83 \pm 3.73^{\mathrm{a}}$ & $23.27 \pm 0.74^{\mathrm{b}}$ \\
\hline
\end{tabular}

Data presented in mean \pm standard error. Different letters on the same line indicate statistical differences by Tukey's test $(P<0.05)$. SCR: Surface coverage rate.

2008). In addition, high stocking density causes discontinuous consumption of food resulting from frequent collisions among the post-larvae, since the post-larvae close their valves and stop feeding due to the mechanical shock (LOOSANOFF \& DAVIS, 1963; LIMA et al., 2018), impairing survival and growth of the post-larva. In this study, probably, the continuous water flow, together with increased stocking density, contributed to the increase of the post-larvae collisions.

In post-larvae culture of $A$. brasiliana, LIMA et al. (2018) when testing the density of 60 and 120 post-larvae $\mathrm{cm}^{-2}$, also observed that survival and growth of organisms is influenced by the density of culture. These authors reported survival and growth of $93.81 \%$ and $2,177.34 \mu \mathrm{m}$, for the density of 60 post-larvae $\mathrm{cm}^{-2}$, which resulted in a $48 \%$ increase in length. OLIVA et al. (2014) studied the effect of density on growth and survival, during the initial larval phases and after establishment of the species M. edulis in the laboratory. The authors observed that the density affected the growth of the species, since post-larvae cultured at 5 pediveliger $\mathrm{cm}^{-2}$ density were $28 \%$ larger than the post-larvae cultured at 10 pediveliger $\mathrm{cm}^{-2}$. The best results for survival were also obtained at lower densities, reaching up to $68 \%$. These results agree with the present study, where the density affected the growth and the survival during the post-larval phase of $A$. brasiliana.

The static system with total water exchanges every 48 hours is commonly used in larval and post-larval bivalve cultivation (ROBERT \& GERARD, 1999). RAGG et al. (2010) recommend the continuous water flow to larviculture using smaller volumes and high densities of larvae or postlarvae. The continuous flow cultivation system is more efficient than the static system, with or without changing the water, presenting in general higher survival results (TURINI et al., 2014); however, even in this system, the high density affected the yield of Anomalocardia brasiliana post-larvae in this study.

Studies showed that the background area can limit density for larvae with benthic habits. In post-larvae foot there is a reduction in growth when subjects occupy $100 \%$ or more of the bottom coverage area of the experimental unit (LIU et

Table 2 - Specific growth rate (SGR) Anomalocardia brasiliana post-larval settlement in three different storage densities cultivated for each period (days).

\begin{tabular}{|c|c|c|c|c|c|}
\hline & \multicolumn{5}{|c|}{ SGR $\left(\%\right.$ day $\left.^{-1}\right)$} \\
\hline \multirow[t]{2}{*}{ Stocking density(post-larvae $\mathrm{cm}^{-2}$ ) } & \multicolumn{5}{|c|}{ Period of cultivation (days) } \\
\hline & $0-7$ & $7-14$ & $14-21$ & $21-28$ & $0-28$ \\
\hline 40 & $8.21 \pm 0.33^{\mathrm{a}}$ & $6.00 \pm 0.32^{\mathrm{a}}$ & $0.37 \pm 0.32^{\mathrm{b}}$ & $5.02 \pm 0.32^{\mathrm{a}}$ & $4.98 \pm 0.08^{\mathrm{a}}$ \\
\hline 80 & $8.44 \pm 0.27^{\mathrm{a}}$ & $3.91 \pm 0.30^{\mathrm{b}}$ & $1.47 \pm 0.26^{\mathrm{a}}$ & $2.27 \pm 0.30^{\mathrm{b}}$ & $4.08 \pm 0.07^{b}$ \\
\hline 160 & $8.52 \pm 0.23^{\mathrm{a}}$ & $2.73 \pm 0.23^{\mathrm{c}}$ & $1.19 \pm 0.34^{\mathrm{ab}}$ & $0.82 \pm 0.29^{c}$ & $3.37 \pm 0.07^{\mathrm{c}}$ \\
\hline
\end{tabular}

Data presented in mean \pm standard error. Different letters on the same column indicate statistical differences by Tukey's test $(P<0.05)$. 
al., 2010). HEASMAN et al. (2002) noted that an occupation of $70 \%$ of the bottom area is a limiting factor for the development of juvenile scallops (Pecten fumatus) as density is a limiting factor of their growth rate. For Clinocardium nuttallii however, a full use of the bottom area $(100 \%)$ is possible, if individuals are not longer than $1 \mathrm{~mm}$ in length; in such case, a density of 160 post-larvae $\mathrm{cm}^{-2}$ would be recommended (LIU et al., 2010). In the present study, the bottom coverage area was not a growth limiting factor to A. brasiliana, it was observed that, due to the high mortality, the treatment with 160 post-larvae $\mathrm{cm}^{-2}$ presented similar SCR values of the treatment with low density and the higher SCR was obtained in 80 post-larvae $\mathrm{cm}^{-2}$, at the end of cultivation.

The specific growth rate of Meretrix meretrix larvae was lower than $2 \%$ when they were in the period of metamorphosis and settlement, regardless of the stocking density (LIU et al., 2006). In the case of $A$. brasiliana post-larvae; although, it was at a different stage, there was a drop in SGR $(<2 \%)$ on the $21^{\text {st }}$ day. After 24 days of cultivation, post-larvae at the lowest density (40 post-larvae $\mathrm{cm}^{-2}$ ) reached $1 \mathrm{~mm}$ in length. Such growth was not achieved in other densities; post-larvae growth rate at higher densities was lower, affecting the final size of individuals at the end of the cultivation. If a $600 \mu \mathrm{m}$ length is desirable, a density of 160 post-larvae $\mathrm{cm}^{-2}$ can be used. If a $1 \mathrm{~mm}$ length is the target, the suitable density is of 40 post-larvae $\mathrm{cm}^{-2}$. In both cases, the maximum growth rate would be maintained.

\section{CONCLUSION}

Stocking density directly affects growth and survival rates of settled $A$. brasiliana post-larvae. In a closed culture system, the density of 160 postlarvae $\mathrm{cm}^{-2}$ can be used until the post-larvae reach $600 \mu \mathrm{m}$ in length, then they should be in density of 40 post-larvae $\mathrm{cm}^{-2}$ to maintain the specific growth rate at around $5 \%$ per day.

\section{ACKNOWLEDGMENTS}

This study had the support of Brazilian National Counsil for Scientific and Technological Development (CNPq) for the aid granted to the Professor Alfredo Olivera Gálvez (PQ 311058/2015-9), Coordenação de Aperfeiçoamento de Pessoal de Nível Superior (CAPES), Brazil - Finance code 001, and Fundação de Amparo à Ciência e Tecnologia do Estado de Pernambuco (FACEPE).

\section{ETHICS AND BIOSSECURITY COMMITTEE APROVAL}

The study did not require the approval of an institutional ethics committee, since the work was developed with oysters (bivalve mollusks), not falling under Art. 2 of Law 11.974 of October 8, 2008: "The provisions of this Law apply the animals of the species classified as phylum Chordata, subphylum Vertebrata, observing the environmental laws".

\section{DECLARATION OF CONFLICT OF INTERESTS}

The authors declare no conflict of interest. The founding sponsors had no role in the design of the study; in the collection, analyses, or interpretation of data; in the writing of the manuscript, and in the decision to publish the results.

\section{AUTHORS' CONTRIBUTIONS}

All authors contributed equally for the conception and writing of the manuscript.

\section{REFERENCES}

CHRISTO, S. W.; ABSHER, T. M. Reproductive period of Crassostrea rhizophorae (GUILDING, 1828) and Crassostrea brasiliana (Lamark, 1819) (Bivalvia: ostreidae) in Guaratuba bay, Paraná, Brazil. Journal of Coastal Research, v.39, p.1215-1218, 2006. Available from: <https://www.jstor.org/ stable/25741779?seq=1\#page_scan_tab_contents $>$. Accessed: Dec. 19, 2018.

CORTE, G. N.; et al. Environmental influence on population dynamics of the bivalve Anomalocardia brasiliana. Estuarine, Coastal and Shelf Science, v.187, p.241-248, 2017. Available from: <https://doi.org/10.1016/j.ecss.2017.01.016>. Accessed: Dec. 19, 2018

EPELBAUM, A. et al. Effects of stocking density and substratum on the survival, growth, burrowing behaviour and shell morphology of juvenile basket cockle, Clinocardium nuttallii: implications for nursery seed production and field outplanting. Aquaculture research, v.42, n.7, p.975-986, 2011. Available from: $<$ https://doi. org/10.1111/j.1365-2109.2010.02680.x>. Accessed: Dec. 19, 2018.

FAO. Fishery and Aquaculture Statistics 2016. FAO: Rome, Italy. 2018. <Available from: http://www.fao.org/state-of-fisheriesaquaculture $>$. Accessed: Dec. 19, 2018.

FANG, Jianguang; LIN, Zhihua. Development of Manila clam industry in China. Bulletin of Japan Fisheries Research and Education Agency Number, v.42, p.29-34, 2016. Available from: <http://www.fra.affrc.go.jp/bulletin/bull/bull42/42-07.pdf>. Accessed: Dec. 19, 2018.

FUNO, I. C. S. A. et al. Recruitment of oyster in artificial collectors on the Amazon macrotidal mangrove coast. Ciência Rural, v.49, n.3, p.e20180482, 2019.

GALVÃO, M. S. N. et al. Desempenho da criação da ostra de mangue Crassostrea sp. a partir da fase juvenil, em sistema suspenso, no estuário de Cananéia e no mar de Ubatuba (SP, Brasil). Boletim do Instituto de Pesca, v.35, n.3, p.401-411, 2009. 
HEASMAN, M. P. et al. Alternative means of nursery culture for commercial scallop (Pecten fumatus Reeve) spat. Aquaculture, v.213, n.1-4, p.323-338, 2002. Available from: <https://doi. org/10.1016/S0044-8486(02)00354-X> Accessed: Dec. 19, 2018.

HUO, Z. et al. Temperature challenge on larvae and juveniles of the Manila clam Ruditapes philippinarum. Aquaculture Research, v.49, n.4, p.1727-1731, 2018. Available from: $<$ https:// doi.org/10.1111/are.13600>. Accessed: Dec. 19, 2018.

LAVANDER, H. D. et al. Biologia reprodutiva da Anomalocardia brasiliana (Gmelin, 1791) no litoral norte de Pernambuco, Brasil. Revista Brasileira de Ciências Agrárias, v.6, n.2, 2011. Available from: <http://www.redalyc.org/ html/1190/119018545023/>. Accessed: Dec. 19, 2018

LEGAT, J. F. A. et al. Effects of salinity on fertilization and larviculture of the mangrove oyster, Crassostrea gasar in the laboratory. Aquaculture, v.468, p.545-548, 2017. Available from: $<$ https://doi.org/10.1016/j.aquaculture.2016.11.016>. Accessed: Dec. $19,2018$.

LIMA, P. C. M. de et al. Larviculture of the sand clam cultivated in different densities. B. Inst. Pesca, v.44, n.2, p.1-7, 2018.

LIU, B. et al. Effect of stocking density on growth, settlement and survival of clam larvae, Meretrix meretrix. Aquaculture, v.258, n.1-4, p.344-349, 2006. Available from: <https://doi.org/10.1016/j. aquaculture.2006.03.047>. Accessed: Dec. 19, 2018.

LIU, W. et al. Effects of stocking density, algal density, and temperature on growth and survival of larvae of the basket cockle, Clinocardium nuttallii. Aquaculture, v.299, n.1-4, p. 99-105, 2010. Available from: <https://doi.org/10.1016/j. aquaculture.2009.11.023>. Accessed: Dec. 20, 2018.

LOOSANOFF, V. L.; DAVIS, H. C. Rearing of bivalve mollusks. In: Advances in marine biology. Academic Press, 1963. p. 1-136.

LOPES, G. R. et al. Growth of Crassostrea gasar cultured in marine and estuary environments in Brazilian waters. Pesquisa Agropecuária Brasileira, v.48, n.8, p.975-982, 2013. Available from: <http://dx.doi.org/10.1590/S0100-204X2013000800024>. Accessed: Dec. 19, 2018.

MONTI, D. et al. Demography and growth of Anomalocardia brasiliana (Gmelin) (Bivalvia: Veneridae) in a mangrove, in Guadeloupe (French West Indies). Journal of Molluscan Studies, v.57, n.2, p.249-257, 1991. Available from: $<$ https://doi. org/10.1093/mollus/57.2.249>. Accessed: Dec. 19, 2018.

MOUËZA, et al. Embryonic, larval and postlarval development of the tropical clam, Anomalocardia brasiliana (Bivalvia, Veneridae) Journal of Molluscan Studies, v.65, n.1, p.73-88, 1999. Available from: <https://doi.org/10.1093/mollus/65.1.73>. Accessed: Dec. $19,2018$.

NICOLAS, L.; ROBERT, R. The effect of food supply on metamorphosis and post-larval development in hatchery-reared Pecten maximus. Aquaculture, v.192, n.2-4, p.347-359, 2001. Available from: <https://doi.org/10.1016/S0044-8486(00)004622>. Accessed: Dec. 19, 2018.

OLIVA, D. P. et al. Effect of stocking density and food ration on growth and survival of veliger and pediveliger larvae of the taquilla clam Mulinia edulis reared in the laboratory. Revista de biología marina y oceanografía, v. 49, n.3, p.567-575, 2014. Available from:
$<$ https://dialnet.unirioja.es/servlet/articulo? codigo $=5230198>$. Accessed: Dec. 19, 2018.

OLIVEIRA, I. et al. Spatial and temporal distribution of the shellifish Anomalocardia brasiliana (Gmelin, 1791) on Mangue Seco beach, Pernambuco, Brazil.Intenational Journal of Aquatic Science, v.2,n.1, p.68-79, 2011. Available from: <http://www.journal-aquaticscience. com/article_73583_c187f4f4ca93892b46725f7d423a9763.pdf>. Accessed: Dec. 19, 2018.

OLIVEIRA, I. B. et al. Efeito do período chuvoso na extração do molusco bivalve Anomalocardia brasiliana (Gmelin, 1791). Revista Brasileira de Ciências Agrárias, v.9, n.1, 2014. Available from: $<$ https://www.redalyc.org/html/1190/119030125023/>. Accessed: Dec. 19, 2018.

OLIVEIRA, M. D.; OLIVEIRA, M. H. R. Dicionário conquílio malacólogico. Juiz de Fora: Ministério da Educação e Cultura. 190p, 1974

POLI, C. R. Cultivo de ostras do Pacífico (Crassostrea gigas, 1852). POLI, C.R. et al.Aquicultura: experiências brasileiras. Florianópolis: Multitarefa, p. 251-266, 2004. Accessed: Dec. 19, 2018.

RAGG, N. LC et al. Optimising the delivery of the key dietary diatom Chaetoceros calcitrans to intensively cultured Greenshell ${ }^{\mathrm{TM}}$ mussel larvae, Perna canaliculus. Aquaculture, v.306, n.1-4, p.270-280, 2010. Available from: <https://doi.org/10.1016/j. aquaculture.2010.05.010>. Accessed: Dec. 19, 2018.

RAGHAVAN, G.; GOPINATHAN, C. P. Effects of diet, stocking density and environmental factors on growth, survival and metamorphosis of clam, Paphia malabarica (Chemnitz) larvae. Aquaculture research, 2008. Available from: $<$ http://agris. fao.org/agris-search/search.do?recordID=US201300905210>. Accessed: Dec. 19, 2018.

ROBERT, R.; GÉRARD, A. Bivalve hatchery technology: the current situation for the Pacific oyster Crassostrea gigas and the scallop Pecten maximus in France. Aquatic Living Resources, v.12, n.2, p.121-130, 1999. Available from: <https://doi. org/10.1016/S0990-7440(99)80021-7>. Accessed: Dec. 19, 2018.

SILVA-CAVALCANTI, J. S.; COSTA, M. F. Fisheries in protected and non-protected areas: is it different? The case of Anomalocardia brasiliana at tropical estuaries of northeast Brazil. Journal of Coastal Research, p.1454-1458, 2009. Available from: <https:// www.jstor.org/stable/25738030?seq=1\#page scan tab contents $>$. Accessed: Dec. 19, 2018.

SPRUNG, M. A. Physiological energetics of mussel larvae (Mytilus edulis). I. Shell growth and biomass. Marine ecology progress series. Oldendorf, v.17, n.3, p.283-293, 1984. Available from: <https://www.int-res.com/articles/meps/17/m017p283.pdf>. Accessed: Dec. 19, 2018.

TURINI, C. S. et al. Effects of stocking-density in flowthrough system on the mussel Perna perna larval survival. Acta Scientiarum. Animal Sciences, v.36, n.3, p.247-252, 2014. Available from: <http://dx.doi.org/10.4025/actascianimsci. v36i3.23685>. Accessed from: Dec. 19, 2018.

VELASCO, L. A.; BARROS, J. Experimental larval culture of the Caribbean scallops Argopecten nucleus and Nodipecten nodosus. Aquaculture Research, v.39, n.6, p.603-618, 2008. Available from: <https://doi.org/10.1111/j.1365-2109.2008.01917.x>. Accessed: Dec. 19, 2018. 